\title{
СОСТОЯНИЕ И ПЕРСПЕКТИВЫ РАЗВИТИЯ МИРОВОЙ ВОДОРОДНОЙ ЭНЕРГЕТИКИ
}

\author{
И.А. Макарян, И. В. Седов \\ ИРЭН АРМЕНОВНА МАКАРЯН - кандидат химических наук, ведущзий научный сотрудник Института \\ проблем химической физики Российской Академии наук (ИПХФ РАН), руководитель группь конъюнктурных \\ и технико-экономических исследований.E-mail: irenmak@icp.ac.ru.
}

ИГОРЬ ВЛАДИМИРОВИЧ СЕДОВ - кандидат химических наук Института проблем химической физики Российской Академии наук (ИПХФ РАН), заведующий химико-технологическим отделом.

E-mail: isedov@icp.ac.ru.

142432, Московская обл., г. Черноголовка, проспект академика Семенова, 1. Институт проблем химической физики РАН, Черноголовка, Россия.

В обзоре анализируется развитие рынка водородной энергетики, обсуждаются национальнье программы поддержки этой новой отрасли мировой энергетики и пилотныле водородныле проектьл. Рассматриваются вопросы производства, потребления, аккумулирования, хранения и транспортировки водорода. Дана оченка состояния мирового и российского рынков водорода по основным конъюнктурным показателям и перспективы их развития на ближайшие годы.

Ключевые слова: водород, водородная энергетика, декарбонизация, инфраструктура водорода, рынок водорода, прогноз развития рынка.

\section{STATE AND PROSPECTS FOR DEVELOPMENT OF GLOBAL HYDROGEN POWER ENGINEERING}

\author{
I.A. Makaryan, I. V. Sedov
}

Academician Semenov avenue 1, Chernogolovka, Moscow region, 142432, Russian Federation Institute of Problems

of Chemical Physics of Russian Academy of Sciences (IPCP RAS).

Development of hydrogen power engineering market, national programs for supporting such a new sector of global energetic and hydrogen pilot projects are analyzed in this review. The matters of hydrogen production, its supply and demand, accumulation, storage and transportation are discussed. States of the world and Russian markets are analyzed and forecast of markets progress in the nearest future is given.

Key words: hydrogen, hydrogen power engineering, decarbonization, hydrogen infrastructure, hydrogen market, market forecast. 


\section{Введение}

Известно, что традиционные ископаемые топлива нуждаются в повышении эффективности, губительно воздействуя на мировую экологическую обстановку, что способствует всё большему ужесточению стандартных нормативов по охране окружающей среды. Поэтому не случайно в последние годы наметилась крайняя необходимость в разработке и освоении новых технологий, позволяющих генерировать, сохранять и передавать энергию без/при минимизации выбросов в атмосферу парниковых газов (прежде всего $\mathrm{CO}_{2}$ ), что относят к так называемому «углеродному следу».

Новая зарождающаяся отрасль мировой энергетики - водородная энергетика - основана на использовании в качестве средства для аккумулирования, транспортировки, производства и потребления энергии такого соединения, как водород. Наряду с этим, фактически в стадии становления находятся мировой и региональные рынки водородной энергетики. К видению именно такой энергетики как основного направления развития эффективных и экологически чистых энергетических систем пришли независимо друг от друга ученые в разных странах мира. Дело в том, что водород в чистом виде или в сочетании с некоторыми другими видами топлива можно наиболее эффективно преобразовывать в энергию. При горении водорода образуется только чистая вода, которая вовлекается в повторный водородный цикл [1]. Сам водород относится к наиболее распространенным элементам на поверхности земли и в космосе, однако он не является первичным источником энергии, поскольку не встречается в свободном виде в традиционных природных месторождениях. При этом до сих пор водород в основном используется не в качестве топлива, а как исходное промышленное сырье, в первую очередь для получения аммиака, метанола, а также в нефтепереработке.

Энергетическая ценность водорода выше, чем у метана (теплота его сгорания составляет 120 МДж/кг по сравнению с 56 МДж/кг у метана), что вызывает интерес применения водорода в качестве топлива для транспортных средств. Однако если весовая энергетическая плотность водорода высокая, то по объему этот показатель низкий (даже когда водород сильно сжат или находится в жидком состоянии, его энергетическая плотность по объему составляет лишь $1 / 4$ часть этого показателя для бензина). Единственный и существенный недостаток водорода заключается в том, что он является одним из самых известных взрывои пожароопасных соединений и его применение связано с серьезными ограничительными стандар- тами (особенно при его использовании в качестве топлива).

В наши дни доминирует углеродная энергетика, транспорт в основном работает на нефтяном сырье, а отопление производится за счет природного газа, при этом спрос на эти энергетические продукты растет, особенно в Китае, Индии и многих других развивающихся странах. Водород может стать экологически чистым источником энергии для конечных потребителей без выделения в атмосферу таких вредных примесей, как взвеси выхлопных газов или диоксид углерода. Подсчитано, что для того чтобы к 2050 г. замедлить прирост потепления до 2 градусов в год нужно будет перевести 400 млн. частных автомобилей, 15-20 млн. грузовиков и 5 млн. единиц общественного транспорта на водородное топливо, на что в мире потребуются ежегодные инвестиции в размере 20-25 млрд. долл. [2]. Декарбонизация и низкоуглеродное развитие являются основным трендом нынешней мировой энергетики. Ведущие страны мира, отдельные регионы и крупные корпорации декларируют свои долгосрочные стратегические цели по снижению выбросов парниковых газов (или углеродного следа в выпускаемой продукции) для борьбы с глобальным изменением климата (табл. 1) [3].

В десятку лидеров по абсолютным значениям выбросов парниковых газов входят такие страны, как Китай, США, Индия, Россия, Япония, Германия, Южная Корея, Иран, Саудовская Аравия и Канада, на долю которых в 2017 г. пришлось 67 \% общих мировых выбросов [4].

Если в долгосрочной перспективе водородная энергетика будет развиваться успешно, а ее мировой рынок будет характеризоваться значительными масштабами производства и постоянным увеличением спроса на его применение, то со временем водород может даже стать универсальным, самым дешевым и экологически чистым энергоносителем.

Целью настоящего обзора является анализ основных тенденций и критериев для успешного становления глобальной водородной энергетики, а также рассмотрение состояния и перспектив развития зарождающихся рынков мировой и российской водородной энергетики. Обзор является продолжением наших ранее опубликованных аналитических обзоров по водородной тематике $[5,6]$.

\section{Этапы становления и развития рынка водородной энергетики}

Исследовательские работыпо водородной энергетике как альтернативному пути развития энергетики значительно активизировались в первой половине 1970-х годов, в разгар мирового энергети- 
Заявленные национальные цели по сокращению выбросов парниковых газов [3]

\begin{tabular}{ll}
\hline \multicolumn{1}{c}{ Страна } & \multicolumn{1}{c}{ Декларируемые сокращения выбросов парниковых газов } \\
\hline США & к 2025 г. сократить выбросы парниковых газов на 26-28 \% от уровня 2005 г. \\
Канада & к 2030 г. - на $30 \%$ от уровня 2005 г. \\
Германия & к 2030 г. - на 40-55 \% от уровня 1990 г., к 2050 г. - на 80-95\%. \\
Франция & к 2030 г. - на $40 \%$ от уровня 1990 г. \\
Норвегия & к 2030 г. - на $40 \%$ от уровня 1990 г. \\
Бразилия & к 2025 г. - на 40\% от уровня 2005 г. \\
Мексика & к 2030 г. - на 22-36 \% от базовой линии \\
Китай & к 2030 г. сократить удельные выбросы парниковых газов на 1 долл. ВВП на 65 \% \\
Австралия & К выходом на пик по абсолютной величине выбросов не позднее 2030 г. \\
\hline
\end{tabular}

ческого кризиса. Сам термин водородная энергетика, как принято считать специалистами, был впервые предложен Джоном Бокрисом (John Bockris) в компании General Motors в 1970 г. Главный вклад в исследования в этом направлении внесли ученые США, Европы, СССР и Японии. В 2000-х годах внимание к концепции водородной энергетики заметно ослабело, однако интерес вновь возник в середине 2010-х годов. Именно тогда Международное энергетическое агентство (IEA), а также крупнейшие мировые экономики, многие научно-исследовательские, промышленные и инвестиционные структуры стали проявлять повышенный интерес к глобальному переходу на безуглеродную водородную энергетику. Активное участие в этом процессе принимает Министерство энергетики США (United States Department of Energy или DOE).

В последние годы вопрос о необходимости создания альтернативной энергетики встал еще более остро, поскольку заметно ужесточились технологические и экологические требования к используемым сырьевым материалам и технологиям. В январе 2017 г. на корпоративной основе был создан Международный Водородный Совет (Hydrogen Council) [7], объединивший такие крупнейшие мировые энергетические компании, заинтересованные в создании, продвижении и спонсировании глобальной водородной энергетики, как: Air Liquid, Alstom, AngloAmerican, BMW Group, Daimler, Engie, Honda, Hyundri, Kawasaki, Shell, Linde Group, Total и Toyota. Развитие водородной энергетики должно обеспечить снижение выбросов парниковых газов (или следов углерода с производимой продукции) и внести заметный вклад в дело борьбы с глобальным изменением климата. Hydrogen Council определил ключевую роль водо- рода в решении вопросов эффективной водородной энергетики исходя из следующих соображений:

- водород можно получать на основе множества сырьевых источников и процессов, при этом могут варьироваться количества образующихся парниковых или иных вредных газов, а также стоимостные и инфраструктурные показатели;

- водород и водородные топливные ячейки могут постепенно войти в состав всей мировой энергетической системы;

- инфраструктура водородной энергетики является дорогостоящей, однако грамотное использование комбинированных способов передачи энергии может обеспечить более низкие инвестиционные вливания.

Основные переходные этапы последовательного становления и развития мирового рынка водородной энергетики, включая разработку технологий получения водорода, первичное попадание на рынок, инвестиции в водородную инфраструктуру, создание развитой водородной инфраструктуры и окончательное завоевание рынка подробно обсуждаются в [7].

Доля мирового энергетического рынка, использующего технологии с применением водорода, пока еще мала. Этот сектор рынка слишком молод и фактически находится на стадии своего зарождения, однако развивается весьма успешно. Так, уже стала доступна коммерческая водородная продукция: использование водорода в топливных элементах нашло устойчивую нишу на рынке в секторе складских автопогрузчиков; за последние годы в нескольких странах появились коммерческие транспортные средства, работающие на водороде, а на обогрев зданий было продано более 225 тыс. водородных топливных элементов. 
Многие эксперты рынка сходятся во мнении, что в ближайшие 10-15 лет развитие инновационных технологий получения водорода в сочетании с тенденцией мировой экономики к декарбонизации и переходу на водородную энергетику, а также в связи с ужесточающимися экологическими требованиями, могут привести к созданию на рынке вполне конкурентоспособной ниши крупнотоннажного получения водорода в промышленных масштабах [8].

\section{Национальные водородные программы и пилотные проекты}

Ведущие страны мира, отдельные регионы и крупные корпорации имеют свою собственную национальную стратегию по развитию водородных технологий. В США, странах ЕС, Великобритании, Японии, Китае, Южной Корее и Австралии уже действуют программы, направленные на построение водородной энергетики и переход к использованию водородного топлива на транспорте, в электроэнергетике и теплотехнике. Так например, ежегодное финансирование принятой еще в 1970-х годах водородной программы США "US DOE Hydrogen and Fuel Cells Program" сейчас оценивается в 120 млн долларов; в Европейском Союзе действует общеевропейская инициатива "Fuel Cells and Hydrogen Joint Undertaking", созданная в 2017 г., объединившая 22 европейские страны и имеющая проекты общей стоимостью около 1,8 млрд евро на ближайшие пять лет; объемы государственного финансирования японской программы "Strategic Roadmap for Hydrogen and Fuel Cells", созданной в 2014 г., составили в 2017 г. около 310 млн. евро, а общий объем финансирования в Японии до 2040 г. оценивается в несколько млрд. евро. Международный Водородный Совет Hydrogen Council готов обеспечивать инвестиции в НИОКР и развертывание водородных рынков на уровне 1,9 млрд. евро в год в период 2018-2022 гг. [3].

Политика поддержки развития технологий водородной энергетики в разных странах во многом зависит от различия в национальных приоритетах, включая такие показатели, как качество воздуха, изменения климата, энергетическая безопасность, доступность средств, экономический рост и т.д. Например, в США - это чистота воздуха, загрязняемого транспортными средствами, в Китае - качество воздуха в густонаселенных городах. Согласно данным [9], в США объем бюджетных ассигнований на водородные проекты составляет 1,7 млрд. долларов на пять лет (в несколько раз больше средств поступает от частных компаний), в Евро- пейском Союзе- 2 млрд. евро, в Японии- 4 млрд. долларов на 20 лет.

Известно, что программа перехода на водородную энергетику в Японии состоит из нескольких стадий, которые включают поддержку использования водородных топливных элементов в электромобилях, производство водорода и топливных водородных элементов для жилых зданий, разработку и интегрирование водородных систем в общую энергетическую систему к 2030 г. с окончательным переходом на безуглеродную водородную энергетику к 2040 г.

В табл. 2 приводятся данные по прогнозу потребления водорода и водородных топливных элементов в ряде секторов рынка водородной энергетики (комбинированные тепловые и энергетические системы, водородные топливные элементы, водородные заправочные станции) на ближайшие годы в шести лидирующих странах, а в табл. 3 уровень финансовой поддержки для реализации задуманных планов.

Основным стимулом развития рынка водородной энергетики в Европе является снижение эмиссии вредных газов, при этом водород рассматривается как очень важная составляющая государственной стратегии. Такие страны, как Великобритания и Франция, планируют к 2040 г. прекратить продажи новых автомобилей, работающих на бензине и дизельном топливе, а Норвегия собирается уже к 2025 г. заменить продажи дизельных машин и перевести весь пассажирский транспорт на электричество и водород.

В табл. 4 даны суммарные показатели количества водородных установок в основных региональных рынках по состоянию на 2018 г.

В США несколько производителей автомобилей уже приняли решение о разработке транспортных средств на основе водорода, при этом некоторые известные нефтехимические компании создают совместные предприятия по производству водорода различными методами, используя для этого энергию ветра, солнца, электролиз воды и т.д. Кроме того, в США уже имеется развитая система трубопроводов для природного газа, которую можно будет использовать и для транспортировки водорода. В целом во всех странах, где уже работают транспортные средства на основе природного газа, например, в Иране, Китае, Пакистане, Индии, Аргентине, Бразилии, Боливии и др., имеются большие перспективы организации эффективной транспортировки водородного топлива.

Не только в США, но и во многих странах Европейского Союза (Бельгия, Германия, Франция, Нидерланды), также уже есть относительно хорошо развитая система трубопроводов для по- 
Суммарные данные по целевым показателям использования водородных установок по ряду секторов рынка водородной энергетики в разных странах [1]

\begin{tabular}{|c|c|c|c|c|c|c|c|c|}
\hline \multirow[t]{2}{*}{ Страна } & \multicolumn{2}{|c|}{$\begin{array}{c}\text { Комбинированные } \\
\text { системы тепла } \\
\text { и энергии }\end{array}$} & \multicolumn{3}{|c|}{$\begin{array}{c}\text { Автомобили с водородными } \\
\text { топливными элементами }\end{array}$} & \multicolumn{3}{|c|}{$\begin{array}{c}\text { Водородные } \\
\text { заправочные станции }\end{array}$} \\
\hline & 2020 г. & 2030 г. & 2020 г. & 2025 г. & 2030 г. & 2020 г. & 2025 г. & 2030 г. \\
\hline Япония & 1,4 млн. & 5,3 млн. & 40000 & 200000 & 800000 & 160 & 320 & 900 \\
\hline Германия & - & - & $\begin{array}{c}100 \% \text { нулевая } \\
\text { эмиссия } \\
\text { к } 2040 \text { г. }\end{array}$ & - & - & 400 & - & - \\
\hline Китай & - & - & $\begin{array}{l}3000 \text { (только } \\
\text { для Шанхая) }\end{array}$ & 50000 & 1 млн & 100 & 1000 & - \\
\hline США & - & - & 0 & 3,3 млн & - & $\begin{array}{c}100 \text { (только } \\
\text { для Кали- } \\
\text { форнии) }\end{array}$ & - & - \\
\hline Южная Корея & - & $1,2 \mathrm{MBT}$ & 10000 & 100000 & 630000 & 100 & 210 & 520 \\
\hline Великобритания & - & - & $\begin{array}{c}100 \% \text { нулевая } \\
\text { эмиссия } \\
\text { к } 2040 \text { г. }\end{array}$ & - & - & 30 & 150 & - \\
\hline
\end{tabular}

Государственные меры поддержки для реализации программ по энергетическому водороду и водородным топливным элементам в 2017 г. [1]

\begin{tabular}{|c|c|c|c|}
\hline Страна & $\begin{array}{c}\text { Комбинированная } \\
\text { система тепла и энергии } \\
\text { в жилищах }\end{array}$ & $\begin{array}{c}\text { Водородные топливные } \\
\text { элементы транспортных } \\
\text { средств }\end{array}$ & $\begin{array}{c}\text { Заправка водородом } \\
\text { на станциях }\end{array}$ \\
\hline Япония & $\begin{array}{l}93 \text { млн. долл., } \\
700-17000 \text { долл. за единицу }\end{array}$ & 147 млн. долл. & 61 млн. долл. \\
\hline Германия & 13600 долл. за единицу & $\begin{array}{l}4000 \text { долл. за транспортное } \\
\text { средство }\end{array}$ & 466 млн. долл. \\
\hline Китай & - & $\begin{array}{l}1700 \text { долл. за кВ } \\
\text { (до } 57 \text { 000долл. за транспорт- } \\
\text { ное средство) }\end{array}$ & 1,1 млн. за единицу \\
\hline США & $\begin{array}{l}1000 \text { долл. за едини- } \\
\text { цу (до } 3000 \text { долл. за кВ } \\
\text { для больших систем) }\end{array}$ & $\begin{array}{l}\text { До } 13000 \text { долл. за транспорт- } \\
\text { ное средство }\end{array}$ & $\begin{array}{l}30 \text { \% цены (до } 30000 \text { долл.); } \\
\text { в Калифорнии } 100 \text { млн. долл. } \\
\text { к } 2023 \text { г. }\end{array}$ \\
\hline Южная Корея & 5,3 млн. & $\begin{array}{l}\text { 5,4 млн. (до } 31 \text { 000долл. } \\
\text { за транспортное средство) }\end{array}$ & \\
\hline Великобритания & - & $\begin{array}{l}33 \text { млн. долл. (60 \% цены } \\
\text { для заправки) }\end{array}$ & \\
\hline
\end{tabular}

дачи природного газа. В Великобритании в соответствии с национальными пилотными водородными программами уже протестированы автобусы, работающие на водородных топливных элементах, а специальная экспедиция проверяет возможности установки таких устройств на мор- ских судах. Ранее работа автобусов на водородном топливе была протестирована в пилотном режиме в Австралии (водород поступал с нефтеперегонного завода British Petroleum в местечке Kwiana (Перт, Австралия), где его получали в качестве побочного продукта). В соответствии 
Количество водородных установок в мире по состоянию на 2018 г. [4]

\begin{tabular}{lcccc}
\hline Страна & $\begin{array}{c}\text { Комбинированные } \\
\text { системы тепла } \\
\text { и энергии }\end{array}$ & $\begin{array}{c}\text { Водородные } \\
\text { топливные элементы } \\
\text { транспортных средств }\end{array}$ & $\begin{array}{c}\text { Водородные } \\
\text { заправочные } \\
\text { станции }\end{array}$ & $\begin{array}{c}\text { Складские } \\
\text { погрузчики }\end{array}$ \\
\hline Япония & 223000 & 1800 автомобилей & 90 & 21 \\
\hline Германия & 12000 & $\begin{array}{c}467 \text { автомобилей, } \\
14 \text { автобусов }\end{array}$ & 33 & не доступно \\
\hline Китай & 1 & $\begin{array}{c}60 \text { автомобилей, } \\
50 \text { автобусов }\end{array}$ & 36 & 11600 \\
\hline США & 225 МВт & $\begin{array}{c}2750 \text { автомобилей, } \\
33 \text { автобуса }\end{array}$ & $\begin{array}{c}39 \text { общественных, } \\
\text { всего } 70\end{array}$ \\
\hline Южная Корея & 177 МВт & 100 автомобилей & 11 & не доступно \\
\hline Великобритания & 10 & 42 автомобиля, & 14 & 2 \\
\hline
\end{tabular}

с местными национальными программами проверка автобусов, работающих на водородном топливе, сейчас проводится в Бельгии, Норвегии, Индии и Южной Корее. Крупные суммы в развитие водородной энергетики инвестирует Министерство энергетики Турции (компания Istanbul Sea Buses). Возможность организации эффективной и безопасной транспортировки водорода тестируется в рамках пилотных проектов во многих странах, в частности, США (шт. Калифорния, шт. Массачусетс), Канаде, Японии, странах ЕС (Португалия, Норвегия, Дания, Германия) и Исландии. Однако на данный момент подтверждается лишь очень высокая стоимость проектов.

Пока что глобальные инвестиции в водородную энергетику составляют, по разным оценкам, около 0,85-1,4 млрд. евро в год. Совет Hydrogen Council планирует инвестировать 13 млрд. долл. в течение пяти лет в сети водородных заправочных станций и водородные автомобили. По данным DOE, сектор топливных элементов уже дает работу 16000 гражданам (перспектива роста до 200 000), а финансовая поддержка от государственного бюджета США этому сектору составляет около 100 млн. долл. в год на протяжении уже многих лет. В мире проводится также большая работа по снижению стоимости водородных производств, в частности, стоимость получения водорода методом электролиза должна уменьшиться с 11,5 до 5,7 долл. за килограмм. Также запланировано уменьшение стоимости топливных элементов (в три-пять раз) и хранения водорода (в два-три раза) [10]. Вопрос состоит в том, сможет ли водородная энергетика в качестве альтернативы вытеснить углеродную энергетику, и каковы перспекти- вы развития молодого рынка водородной энергетики на ближайшие годы.

\section{Получение водорода в промышленности}

Приводятся данные о том, что в 2018 г. в мире было добыто 4,4 млрд. тонн нефти и 3,86 трлн. ${ }^{3}$ природного газа (метана). Однако объем производства водорода не превысил 70 млн. тонн, то есть объем его выработки был в 6285 раз меньше, чем нефти, и в 5514 раз меньше, чем газа [11]. Молекулярный водород в чистом виде в природных месторождениях отсутствует, а в литосфере по большей части он находится в составе воды.

Существует много способов промышленного получения водорода на основе различных сырьевых материалов. Вначале в качестве исходного сырья использовали ископаемые топлива, при этом выделялся диоксид углерода. Позже стали применять разложение воды, для чего потребовался подвод электрической или тепловой энергии, которые генерировались из первичных источников энергии (ископаемое топливо, атомная энергия, возобновляемая энергия).

Сейчас в мире производится около 45-65 мегатонн водорода в год в качестве исходного сырья для химической и нефтехимической промышленности (что эквивалентно $\sim 1 \%$ мировых поставок энергии), около половины из которых производится паровым реформингом природного газа (метана), 30 \% - парциальным окислением продуктов сырой нефти, $18 \%$ - газафикацией угля и 4 \% - электролизом воды. Разрабатываются также и альтернативные способы производства водорода, включая биохимическое получение, термохимическое 
расщепление воды энергией солнца, высокотемпературный электролиз и др.

С точки зрения эмиссии парниковых газов водород, получаемый различными способами, принято разделять на «серый» водород - его производят из угля, нефти и газа, на «голубой» - полученный на парогазовых электростанциях или атомных электростанциях с применением технологии улавливания и хранения углекислого газа CCS (Carbon Carture and Storage), а также на «зеленый» водород на основе возобновляемых источников энергии с нулевой эмиссией, таких как электролиз воды, методы с использованием силы ветра, солнечной энергии, силы воды, волновой энергии или энергии приливов и отливов. При этом на сегодняшний день 99 \% производимого в мире водорода является «серым» и «голубым», что создает огромный углеродный след [11].

В отличие от хорошо освоенных процессов получения водорода паровым реформингом природного газа, технологии по улавливанию и хранению углекислого газа CCS пока еще далеки от полномасштабной коммерциализации. Сообщается, что в 2018 г. в мире существовали только 18 крупных проектов, использующих CCS технологию по улавливанию углекислого газа, 5 проектов находились на стадии строительства и 20 проектов на различных стадиях готовности [3]. Следует отметить, что согласно технико-экономической оценке, приведенной в исследовании [12], в случае дополнительного введения CCS в технологическую схему процесса получения водорода, капитальные затраты CAPЕХ по технологии паровой конверсии увеличивается на $87 \%$, а эксплуатационные затраты ОРЕХ - на 33 \%, поэтому приведенная стоимость получаемого водорода при этом возрастает в полтора раза (до 1,8 евро за кг), а цена утилизации углекислого газа - до 70 евро за тонну $\mathrm{CO}_{2}$.

Паровой реформинг. В настоящее время паровой риформинг (паровая конверсия) природного газа (метана) или процесс SMR (Steam Methane Reforming) является основным способом промышленного получения водорода (около 90-95 \% мирового выпуска водорода), то есть в промышленных масштабах в качестве исходного сырья используют природный газ (метан) и процесс протекает по уравнению $\mathrm{CH}_{4}+\mathrm{H}_{2} \mathrm{O} \Leftrightarrow \mathrm{CO}+3 \mathrm{H}_{2}$, $(\Delta H=+226$ кДж/моль). Водяной пар при температуре 700-1000 ${ }^{\circ} \mathrm{C}$ смешивается с метаном под давлением в присутствии катализатора, при этом выделяется диоксид углерода. Энергетическая емкость получаемого водорода меньше, чем у исходного топлива, поскольку ее часть теряется на тепло во время производства. Себестоимость водорода, получаемого этим методом, составляет 2-5 долл. за килограмм водорода. [2].

Для того, чтобы полученный таким способом водород можно было использовать в низкотемпературных топливных элементах, потребуются несколько стадий очистки. Применяя адсорбционную технологию (короткоцикловую адсорбцию, КЦА) для отделения водорода от диоксида углерода и других загрязнений, можно достичь чистоты водорода $>99,9$ \%. Стоимость очистки водорода таким методом, сейчас оцененная в 0,7 долл./кг, к 2025 г. должна снизиться до уровня 0,4 долл./кг [1]. Альтернативой этому способу очистки служит мембранно-диффузионный метод под давлением, в котором обычно используются мембраны из металлического палладия. Современные палладиевые мембраны позволяют достичь очень высокой степени чистоты, однако для их работы необходимы высокие рабочая температура $400{ }^{\circ} \mathrm{C}$ и давление 10-15 бар, выход водорода снижается на 3-5 \%, при этом палладиевые мембраны имеют небольшой срок службы.

На сегодняшний день паровая конверсия природного газа (метана) является самым дешевым и наиболее распространенным способом производства водорода. Недостатком метода является высокая эмиссия $\mathrm{CO}_{2}$, которую можно преодолеть с использованием отмеченной выше технологии $\mathrm{CCS}$, однако стоимость водорода при этом будет существенно увеличиваться.

Электролиз воды. Это процесс разложения воды под действием постоянного электрического тока по реакции $2 \mathrm{H}_{2} \mathrm{O}+$ энергия $\rightarrow 2 \mathrm{H}_{2}+\mathrm{O}_{2}$. Таким методом производят небольшое количество водорода (в 2019 г. - на уровне 2 \% от общемирового производства), затрачивая для получения 1 кг $\mathrm{H}_{2}$ около 50 киловатт-часов энергии. Электролизеры используют различные технологии, из которых лидируют электролизеры с протонобменными мембранами (Proton Exchange Membrane или PEM), а твердоокисные электролизеры еще находятся в демонстрационной фазе, однако претендуют на прорыв в индустриальном плане. Имеются данные, что себестоимость процесса электролиза при использовании: а) электричества из промышленной сети составляет 6-7 долл. за килограмм водорода, б) электричества от ветрогенераторов - 7-11 долл., в) солнечной энергии - 10-30 долл. В этом методе используют доступное сырье (воду и электроэнергию), отсутствуют загрязняющие выбросы, получают чистый водород $(99,99$ \%) [13, 14]. Правда, электролиз применяется пока весьма ограниченно (ставки делаются на его высокий потенциал в будущем), а получаемый водород обходится дороже 
водорода по паровой конверсии в 1,5-3 раза, однако имеются все предпосылки для снижения стоимости продукции с применением электролизеров.

Водород из биомассы. Водород из биомассы получается термохимическими (пиролиз, газификация, паровая газификация, паровой риформинг биомасел и газификация с использованием сверхкритической воды) и биохимическими (прямой и непрямой биофотосинтез, биокаталитическая реакция водяного газа, темновая ферментация) способами $[15,16]$. При пиролизе биомасса нагревается при температуре 650-800 К и давлении $0,1-0,5$ МПа в отсутствие воздуха. В зависимости от природы подвергаемой пиролизу биомассы получаются $\mathrm{H}_{2}, \mathrm{CH}_{4}, \mathrm{CO}, \mathrm{CO}_{2}$ и другие газы. В отличие от пиролиза газификация биомассы проводится в присутствии кислорода или воздуха, при этом образуется большое количество газообразных продуктов и небольшое количество смол и золы.

В результате биохимического производства водород получается в качестве побочного продукта метаболизма микроорганизмов. Все процессы здесь катализируются производящими водород энзимами (гидрогеназа и нитрогеназа). Гидрогеназы существуют в большинстве фотосинтетических микроорганизмов (микроводоросли) и подразделяются на поглощающие (действуют как катализаторы поглощения водорода) и обратимые гидрогеназы (способны как производить, так и поглощать водород в зависимости от условий реакции).

Производство водорода в системах атомной энергетики. Это концепция атомно-водородной энергетики, согласно которой водород производится с помощью атомной энергии без вредных выбросов в атмосферу. В мире разработками в области создания технологий ядерного производства водорода занимаются в американских лабораториях Айдахо, ORNL и General Atomics (США), в Институте ядерных и энергетических технологий INET Университета Синьхуа (Китай), Институте атомной энергии JAERI (Япония), Исследовательском институте атомной энергии KAERI (Республика Корея) [17]. Крупнейшие российские энергетические компании «Газпром» и «Росатом» разрабатывают технологии получения водорода с минимальным углеродным следом на основе высокотемпературных атомных реакторов, которые пока находятся на стадии предварительных научных разработок [3]. Сообщается, что специалисты "Росатома" предлагают создать при Кольской АЭС соответствующую инфраструктуру для отработки развиваемых в стране технологий атомно-водородной энергетики [18].
Паровая конверсия метана и электролиз являются базовыми технологиями, вокруг которых, как ожидается, и будет развиваться сектор производства водорода в будущем. Существуют и другие способы получения водорода, находящиеся на более ранних стадиях коммерциализации: это плазменный риформинг, риформинг с применением ионных мембран, микроканальные реакторы, высокотемпературные газоохлаждаемые ядерные реакторы и ряд других.

\section{Области потребления водорода}

До сих пор до 80 \% от общего объема потребления водорода приходятся на два основных сектора - производство аммиака и производство метанола. В химической промышленности водород используют в производстве карбамида, мыла и пластмасс. Ожидается существенное увеличение спроса на водород в нефтеперерабатывающей промышленности, где его применяют для повышения глубины переработки нефти, очистки нефтепродуктов от сернистых загрязнений, увеличения спектра получаемых нефтепродуктов.

Другой крупный сектор применения водорода - топливные элементы, являющиеся наиболее перспективным способом генерации электрической и тепловой энергии из водорода, имеют сравнительно высокие КПД и способны изменять нагрузку в зависимости от широкого диапазона потребности в энергии у потребителей. Подобно солнечным и ветровым электростанциям, топливные элементы являются экологически чистыми источниками, вырабатывающими энергию практически с нулевым углеродным следом. Разрабатываются два типа топливных элементов: низкотемпературные (до $100-120^{\circ} \mathrm{C}$ ) топливные элементы с протонобменными мембранами и высокотемпературные (500-900 $\left.{ }^{\circ} \mathrm{C}\right)$ топливные элементы на основе ионпроводящей керамики. С точки зрения «зеленой» энергетики у водородных топливных элементов крайне высокий КПД - 60 \% (КПД лучших двигателей внутреннего сгорания составляет 35-40 \%, солнечных электростанций - 15-20\%, лучших ветряных электростанций - до $40 \%$ ). Хотя сейчас стоимость водородных топливных элементов относительно стоимости электрических батарей высока, однако полагают, что при массовом производстве их цены к 2025-2030 гг. могут даже сравняться.

В использовании топливных элементов, безусловно, лидирует Япония. Многие известные японские автомобильные компании-гиганты начали серийный выпуск автомобилей, работающих на водородных топливных элементах. Сегмент рынка 
топливных элементов также развивается в Южной Корее, США и Германии, где активно работают над созданием железнодорожных локомотивов, а также подводных лодок и военных кораблей, работающих на водородном топливе (несколько десятилетий назад водородное топливо уже осваивалось в ракетно-космической технике и авиации). Водород сейчас успешно применяется также в автономных источниках электроэнергии мощностью от одного до нескольких тысяч кВт: портативных приборах и аккумуляторах, резервных генератоpax, системах энергообеспечения небольших энергоустановок, беспилотных аппаратах, генераторах для постоянного снабжения теплом и электричеством частных домов и социальных объектов.

Области применения водорода в наши дни: химическая промышленность (получение аммиака, мочевины, удобрений, метанола, диметилового эфира и др.) - 63 \%; нефтеперерабатывающие заводы (процессы гидрокрекинга и гидроочистки) $31 \%$; процессы обработки (восстановление железной руды, добыча газа) - $6 \%$; ракетное топливо, полупроводники, автомобильное топливо $-<1 \%$ [3].

\section{Основные драйверы развития водородного рынка}

Согласно прогнозам компании International Trade Center, рост спроса на водород со стороны сектора аммиака в период 2018-2025 гг. составит $2,5 \%$ в год. В этот же период драйверами развития рынка станут также растущие рынки полупроводников (водород в качестве газа-носителя), удобрений (фосфатные удобрения) и фармацевтики (производство витаминов и пр.) [19]. Отмечается, что, несмотря на то, что водород уже проник во многие отрасли народного хозяйства, производство топливных элементов все еще затруднено в связи с высокими капитальными затратами.

В аналитическом докладе компании Prescient $\&$ Strategic Intelligence в качестве основного драйвера роста рынка отмечается растущий спрос на водород со стороны химической промышленности [20]. Особенно это касается нефтеперерабатывающих отраслей таких стран, как Китай, Индия и страны Ближнего Востока, где будет наблюдаться стремительный рост спроса на водород. Другим важным стимулом развития рынка компания считается спрос на топливные ячейки, поскольку рост инвестиций в исследования и разработки по использованию водорода в качестве топлива является современным трендом мирового рынка водорода. Так, по сообщениям International Energy Agency (IEA), в 2018 г. на рынке существовало уже 8000 машин, работающих на водороде, из них 90 \% при- ходились на США и Японию, к которым постепенно присоединяются и другие страны (например, Правительство Франции выделило на эти цели 116,8 млн. долл.).

\section{Водородная инфраструктура}

Развитие водородной инфраструктуры требует огромных инвестиций (известно, что газопроводы для транспортировки водорода дороже, чем электрические линии дальнего расстояния). Водородная энергетика и экономика водородных производств не могут развиваться без наличия и возможности эксплуатации развитой сети газовых трубопроводов, по которым можно передавать метан-водородную смесь, а затем уже у потребителя разделять эту смесь на водород и метан.

В наши дни водородная инфраструктура пока находится в стадии становления. В основном она держится на крупномасштабном трубопроводном транспорте водорода и оборудованных водородом заправочных станциях, расположенных на транспортных водородных магистралях. Те же заправочные станции, которые расположены вдали от водородных трубопроводов, должны снабжаться водородными баками, трейлерами с сжатым или сжиженным водородом, или же должны монтироваться непосредственно на газовом месторождении. С учетом того, что водород делает сталь хрупкой, тем самым вызывая коррозию и "охрупчивание" стальных газовых трубопроводов, то для последних требуется специальное покрытие. Водород около трех раз объемнее объема природного газа той же энтальпии; он ускоряет растрескивание стали, что повышает эксплуатационные расходы, скорость утечки и стоимость материалов изготовления трубопроводов и резервуаров для хранения.

Передача водорода по трубопроводам является самым дешевым способом его транспортировки. Если для производства водорода доступна возобновляемая энергия (ветровая, солнечная, энергия деления ядра, термоядерная энергия и т.д.), то его использование для получения синтетических топлив может расширить сектор потребления водорода с привязкой к определенному соединительному газопроводу от 5 до 10 раз [21]. Водородные автозаправочные станции (ВАЗС) уже работают в США, Японии, Китае и некоторых странах ЕС. Работой по развитию водородной заправочной инфраструктуры занимаются в таких европейских компаниях, как Air LiquideAir products, Danish Hydrogen Fuel, H2 Logic, Hydrogen Link, Hydrogen Sweden, Icelandic New Energy, Linde, МсPhy. Водородные заправки ВАЗС состоят из системы хранения водорода, охлаждения, компрессора и раз- 


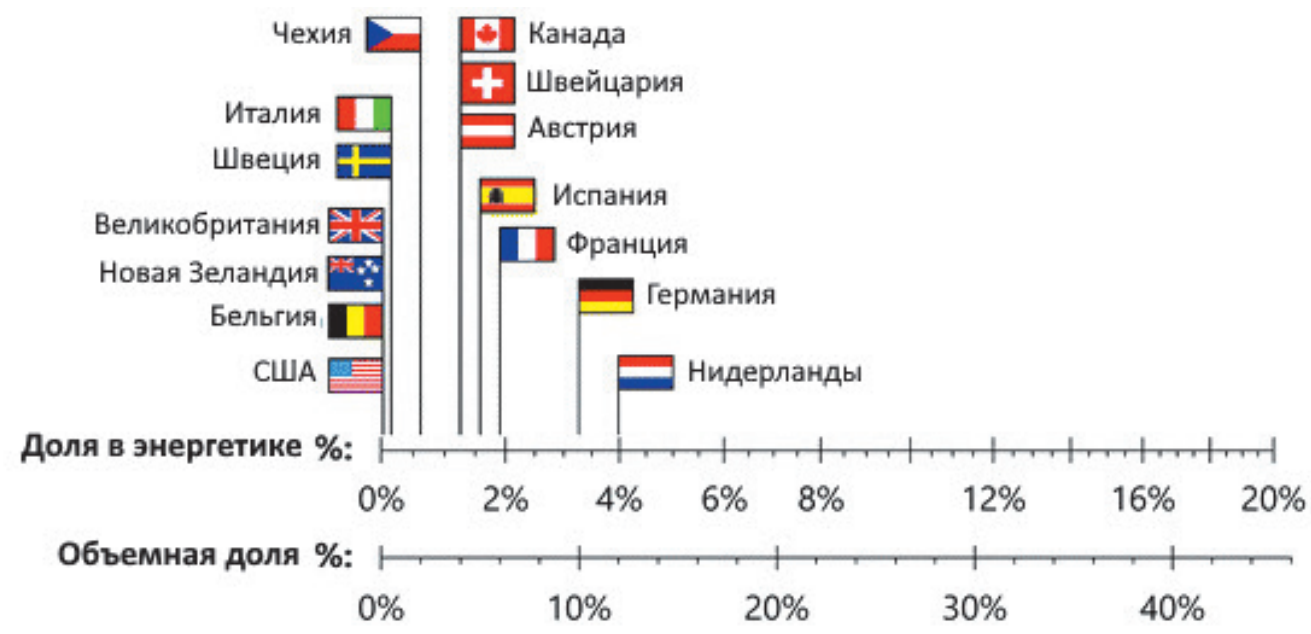

Рис. 1. Ограничения по использованию добавок водорода в сети природного газа в разных странах [1]

даточных устройств для заправки автомобилей. Они проектируются по международным стандартам, а их модульная структура позволяет адаптировать их рабочие характеристики под необходимый объем потребления.

Практикуется также смешивание водорода с природным газом. Так, водород в небольших количествах можно безопасно добавлять в существующие газотранспортные и газораспределительные сети подачи природного газа, однако административные и технические ограничения в разных странах лимитируют допустимое в таких случаях количество водорода. Великобритания и США имеют самый низкий разрешенный уровень $0,1 \%$ (по объему), в то время как в Германии и Нидерландах этот уровень значительно выше и равен $10-12 \%$ (рис. 1) [1]. В Германии есть несколько подобных объектов, в частности, такая станция работает во Франкфурте-на-Майне с 2014 года, добавляя до $2 \%$ водорода в местную газораспределительную сеть. Встречается такое подмешивание водорода в сети природного газа и в Италии, Дании и Нидерландах. Подсчитано, что подмешивание 20 \% водорода в масштабную европейскую газотранспортную систему могло бы снизить выбросы $\mathrm{CO}_{2}$ на 60 млн. тонн в год (или на 7 \%) [11].

\section{Хранение и транспортировка водорода}

Хранение и транспортировка водорода относятся к серьезным барьерам, препятствующим успешному развитию водородной энергетики, поскольку водород представляет собой чрезвычайно летучий и легко воспламеняющийся газ с очень низкой температурой кипения (при комнатной температуре 4 кг водорода занимают объем $45 \mathrm{~m}^{3}$ ). Для его безопасного хранения надо одновременно решить две задачи: добиться увеличения массового содержания водорода в носителе (до 10 \% и более) и подобрать оптимальный диапазон рабочих температур и давлений.

Исходя из природы взаимодействия водорода со средой системы его хранения, все технологии его хранения условно подразделяются разделить на три основные группы:

a) физическое хранение (водород хранится в чистой молекулярной форме в виде газа или жидкости без образования физической или химической связи с другими материалами);

б) физико-химическое хранение (связанная молекула водорода может абсорбироваться на/или в материале хранения за счет слабых физических ван-дер-ваальсовых связей);

в) химическое хранение (в химических соединениях).

Разработаны следующие способы хранения водорода:

- в компримированном виде (до 700 бар, $20-40{ }^{\circ} \mathrm{C}$, стальные или композитные баллоны);

- в сжиженном виде (1 бар, $-252{ }^{\circ} \mathrm{C}$, криогенные емкости);

- в химически связанном виде (жидкие органические гидриды, 1-10 бар, 180-280 ${ }^{\circ} \mathrm{C}$ );

- в обратимо гидрирующихся металлах и сплавах (металлогидриды, 1-5 бар, 100-300 ${ }^{\circ} \mathrm{C}$ );

- в химически связанном виде (жидкий аммиак $\mathrm{NH}_{3}, 350-500$ бар, 400-600 ${ }^{\circ} \mathrm{C}$ ).

Наиболее перспективной формой хранения и транспортировки водорода в химически связанном состоянии является жидкий аммиак (рис 2, табл. 5) [22]. Аммиак способен каталитически разлагаться при температуре $800-900{ }^{\circ} \mathrm{C}$ по реакции $2 \mathrm{NH}_{3} \rightarrow \mathrm{N}_{2}+3 \mathrm{H}_{2}$ и, несмотря на проигрыш в стоимости, пока это единственный промышленный 


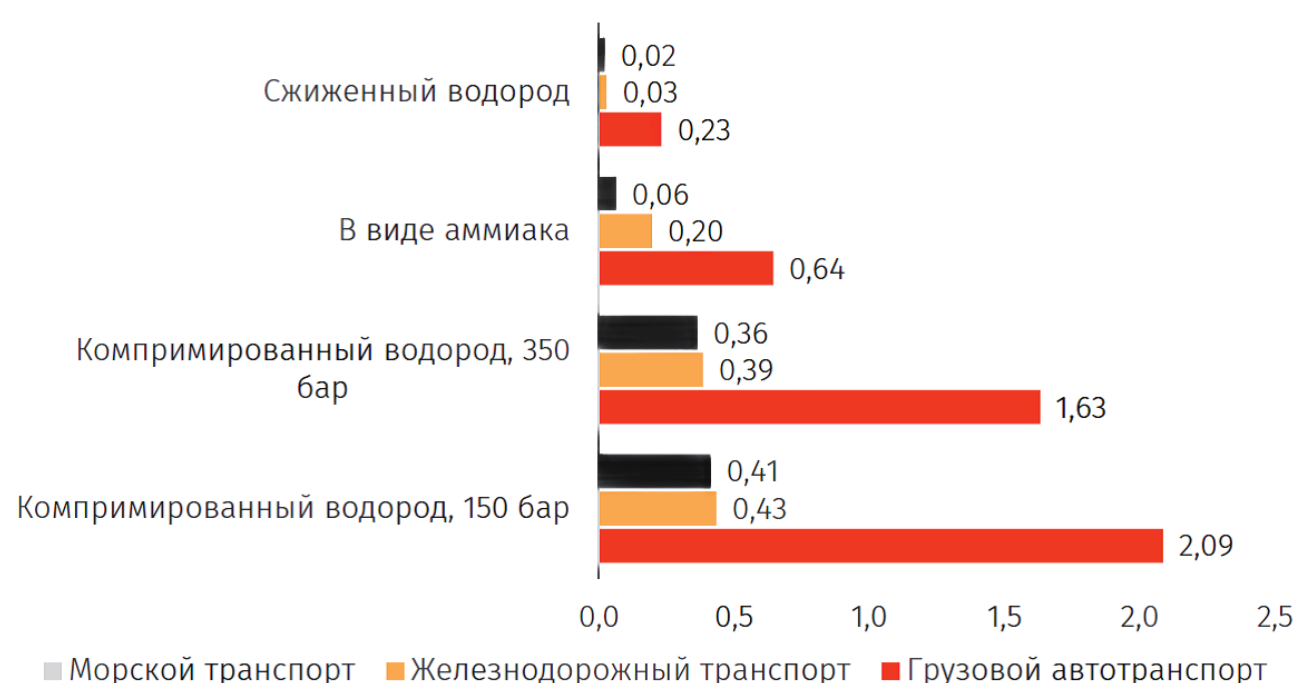

Рис. 2. Стоимость различных форм перевозки водорода (долл./кг) [22]

Таблица 5

Технические характеристики различных способов хранения водорода [22]

\begin{tabular}{lccc}
\hline \multicolumn{1}{c}{ Способ хранения } & $\begin{array}{c}\text { Массовое } \\
\text { содержание } \\
\text { водорода, } \%\end{array}$ & $\begin{array}{c}\text { Рабочие } \\
\text { температуры } \\
\text { процесса, }\end{array}$ & $\begin{array}{c}\text { Рабочие } \\
\text { давления } \\
\text { процесса, бар }\end{array}$ \\
\hline $\begin{array}{l}\text { Стальные баллоны для компримированного } \\
\text { водорода }\end{array}$ & до 1 & $20-40$ & 150 \\
\hline $\begin{array}{l}\text { Композитные баллоны высокого давления } \\
\text { для компримированного водорода }\end{array}$ & $5-7$ & $20-40$ & 350 \\
\hline $\begin{array}{l}\text { Композитные баллоны сверхвысокого } \\
\text { давления для компримированного водорода }\end{array}$ & $10,5-13,8$ & $20-40$ & 700 \\
\hline $\begin{array}{l}\text { Криогенные емкости для сжиженного } \\
\text { водорода }\end{array}$ & до 7,1 & -252 & 1 \\
\hline Жидкие органические гидриды & $1,5-7,5$ & $180-280$ & $1-10$ \\
\hline $\begin{array}{l}\text { Обратимо гидрирующиеся металлы и сплавы } \\
\text { (металлогидриды) }\end{array}$ & до 7,2 & $100-300$ & $1-5$ \\
\hline Жидкий аммиак & 17 & $400-600$ & $350-500$ \\
\hline
\end{tabular}

способ перевозки водорода, наиболее востребованный на рынке.

Развитие и внедрение водородного топлива предполагает создание крупнотоннажных транспортных потоков водорода, которые будут транспортироваться до водородных аналогов крупных газовых хабов и храниться там с последующей доставкой конечному потребителю (формирование водородных хабов).

Известно, что в 2019 г. компании IEA (Infrastructure \& Energy Alternatives, Inc.) и Hydrogen Council создали в Нидерландах водородный газовый хаб, который может обслуживать потоки во- дорода, генерируемого за счет энергии ветров Северного моря, и потоки водорода, импортируемого из третьих стран морским путем. Согласно данным компании S\&P Global Platts (Platts) [23], сейчас основные объемы произведенного водорода сосредоточены на хабах США и Европы, которые являются основными регионами его потребления и куда входят Северная часть побережья Мексиканского залива (США), Калифорния и Нидерланды. География хабов расширяется и совсем скоро они появятся в Азии, особенно Азиатско-Тихоокеанском регионе (АТР). Помимо новых распределительных систем, активно разрабатываются водо- 
родные трубопроводы и заправки, танкеры, автои железнодорожные цистерны, водородные баллоны высокого давления и пр.

Особое значение в инфраструктуре придается возможности реализации распределенной генерации водорода на местах с быстрой доставкой конечным потребителям. Известно, что в США производится около 9 млн. тонн водорода в год, из которых 7,5 млн. тонн расходуются непосредственно в местах его получения, а оставшиеся 1,5 млн. тонн рассматриваются как «торговый» водород [24].

Рост рынка водородной энергетики в любом случае потребует новых решений, поскольку работать придется с большими объемами водорода и дальними расстояниями. В каждом из вариантов транспортировка водорода существуют свои минусы и плюсы относительно энергозатрат, безопасности, удобства использования и т.д. Поэтому при работе с реальным проектом надо будет подбирать конкретные оптимальные варианты для транспортировки водорода, исходя из минимальных затрат по всей логистической цепочке [3].

Активные действия в плане совершенствования и коммерциализации способов хранения предпринимаются в Японии и Австралии, где специально созданные технологические консорциумы (во главе с компаниями Kawasaki Heavy, Mutsui, Chiyoda Corp., Green Ammonia, Tokyo Gas и др.) осуществляют ряд пилотных водородных проектов. Недавно прошло сообщение о том, что в Австралии началась реализация проекта Manilla Community Solar по хранению энергии в «твердом водороде» [25]. Проект включает солнечную электростанцию мощностью 4,95 МВт, литий-ионный накопитель энергии 4,5 МВт/4,5 МВт×ч, водородную систему накопления энергии мощностью 2 МВт и ёмкостью 17 МВтхч. Он поддержан грантом в размере 3,5 млн. австралийских долларов. Солнечная энергия будет преобразовываться в водород, который будет храниться в твердом материале (боргидрид натрия $\mathrm{NaBH}_{4}$ ), а затем по мере необходимости выделяться обратно и направляться в топливный элемент для выработки электроэнергии. Такая система сможет экономно хранить водород при высокой плотности и низком давлении без необходимости энергоемкого сжатия или сжижения. Для хранения потребуются стандартные 20-футовые контейнеры, способные к транспортировке в обычном порядке.

\section{Стоимость водорода}

Ежедневно публикуемые цены на водород, которые обычно приводятся в долларах за кг и евро за кг водорода (\$/кг и евро/кг), отражают получение водорода двумя основными производственными способами: преобладающим паровым риформингом метана и набирающим силу протон-обменным мембранным электролизом (PEM/Proton Exchange Membrane).

Стоимость водорода при получении его различными методами, согласно [11], представлена на рис. 3.

Ценовые прогнозы по стоимости водорода для потребителей таковы: цена водорода у конечного потребителя с доставкой (то есть цена CIF, куда входит стоимость производства, хранения и транспортировки) в зависимости от той или иной

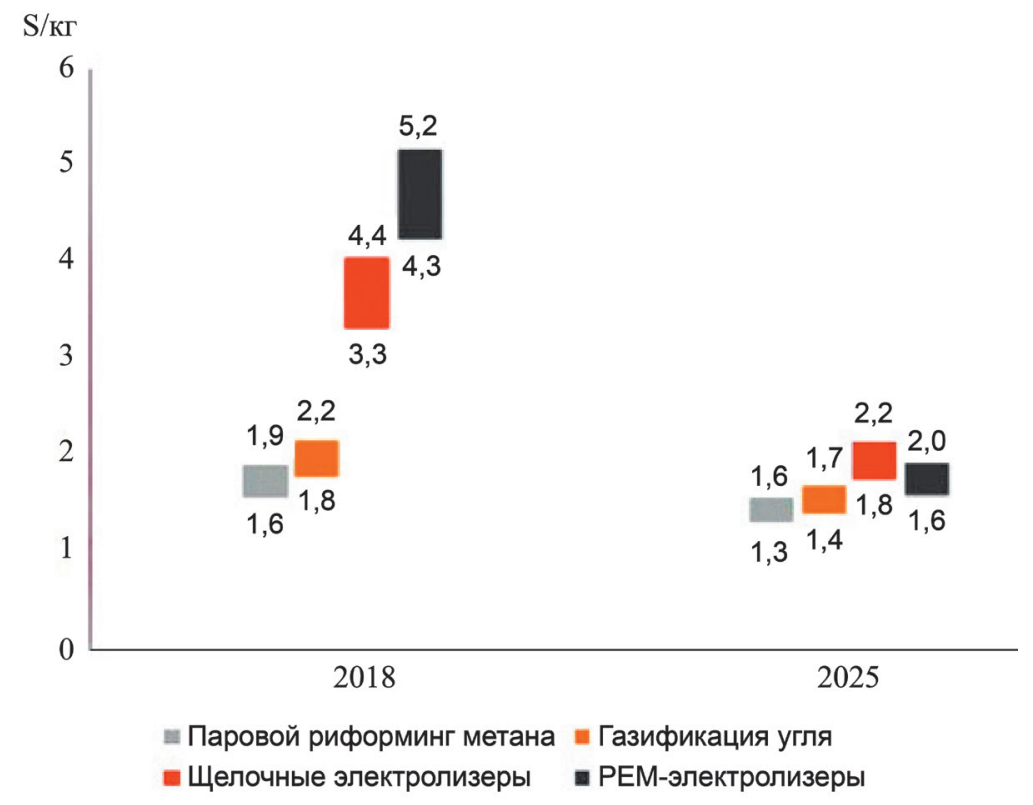

Рис. 3. Приведенная стоимость производства водорода различными методами [11] 
национальной программы по водородной энергетике ожидается в пределах 3-6 \$/кг. Так, в Японии в 2025 г. цена водорода должна составить $3 \$ / \kappa г$, в США - 5 долл./кг, в странах ЕС - 6 \$/кг Как отмечалось выше, в период 2035-2040 гг., согласно прогнозам DOE [26, 27], цена водорода должна снизиться до уровня 2 \$/кг при его мало- и среднетоннажном распределенном производстве.

Стоимость водорода по мере развития рынка существенно снижается. Как правило, ориентиром и барьером для снижения цены высокочистого водорода служит стоимость электричества, которое потребляется для генерации каждого килограмма газообразного водорода, превышающая 35 кВт/ч. Известен факт, что стоимость водорода, полученного паровой конверсией, пока приблизительно в три раза превышает стоимость природного газа на единицу полученной энергии. Несмотря на то, что многие эксперты скептически относятся к тому, что полученный из возобновляемых источников водород когда-нибудь станет доступен по низкой цене [8], водород, получаемый за счет энергии ветра в Германии и шт. Техасе (США), уже сейчас конкурентоспособен по стоимости при организации его малои среднемасштабного производства. Технико-экономические расчеты показали, что экономически выгодно производить водород по цене 3,23 \$/кг в Германии и по цене 3,53 \$/кг в Техасе, при этом более предпочтительно налаживать производство водорода не в Германии, а в Великобритании, поскольку здесь природные условия характеризуются большим количеством ветров.

Что касается цен на товарный водород на каждом из действующих водородных хабов, то они учитывают многие факторы, включая стоимость исходного природного газа и электричества, различные технологические требования (допускается ли наличие парниковых газов или нет), оценки разных вариантов стоимостей (учитываются ли только эксплуатационные затраты ОРЕХ или же добавляются еще и капитальные затраты CAPEX) и многое другое [21].

Американское информационное агентство Platts (S\&P Global Platts), занимающееся различными ценовыми котировками, публикует, в частности, и рыночные цены на водород в различных регионах мира, а также цены на специализированных региональных хабах. Кроме того, в случае необходимости Platts может коррелировать цену на водород с ценами таких молекул-носителей водорода для его хранения и транспортировки, как например, аммиак и др. Согласно Platts, в декабре 2019 г. цена на водород, полученный в Нидерландах по процессу SMR $\left(99,9 \% \mathrm{H}_{2}\right)$ без использования процесса CCS, составила 0,7955 \$/кг [21].
Согласно данным компании Research \& Markets, стоимость водородных топливных элементов для автомобилей, которая в 2000 г. составляла 275 долл. за 1 кВт мощности, в 2005 г. упала более чем в два раза (до 110 долл. за кВт) [28], а благодаря совершенствованию и модернизации технологий производства, те системы на основе водородных топливных элементов, которые в 2005 г. продавались по 60 тыс. долл., теперь стоят около 10 тыс. долл.

\section{Прогноз развития мирового рынка водорода}

В список ведущих компаний по производству водорода, согласно данным аналитической компании Maketsandmarkets, входят: Air Liquide (Франция), Air Products and Chemicals (США), Iwatani (Япония), Hydrogenics (Канада), Linde (Германия) и Praxair (США). Из других известных игроков в водородном бизнесе отмечают компании Messer Group (Гермпния), Showa Denko (Япония), Ally Hi-Tech (Китай), Caloric (Германия), Claind (Италия), Erredue (Италия), HyGear (Нидерланды), Nuvera Fuel Cells (СШA), Proton OnSite (США), Taiyo Nippon Sanso (Япония), Teledyne Energy Systems (США), Хеbec (Канада), Ballard Power Systems (Канада), FuelCell Energy (США) и Plug Power (США) [29].

Компания Air Liquide является лидирующим поставщиком промышленных газов (водорода, кислорода и азота) для химической, нефтехимической, нефтеперегонной и сталелитейной отраслей и ряда предприятий здравоохранения. В сентябре 2018 г. Air Liquide открыла свою 10-ю в Германии водородную станцию и новое производство в Hobro (Дания) по выпуску чистого безуглеродистого водорода.

Существуют различные прогностические оценки достижимых объемов мирового рынка энергетического водорода, основанные на консервативном, умеренном и оптимистичном сценарии развития. Согласно умеренному сценарию, принятому в качестве базового, к 2025 г. мировой рынок водородной энергетики должен достичь 26 млрд. долл. (рис. 4) [22], при этом в период 2025-2040 гг. цены на водородное топливо должны снижаться с 4 тыс. до уровня 2 тыс. долл. за тонну.

В период 2012-2016 гг. мировой рынок водорода устойчиво развивался. Что касается прогнозов различных аналитических компаний по его развитию, то в целом они совпадают, хотя иногда наблюдаются и некоторые различия.

Так, согласно прогнозам компании Persistence Market Research [30], в период 2017-2025 гг. среднегодовой рост мирового рынка водорода в целом 


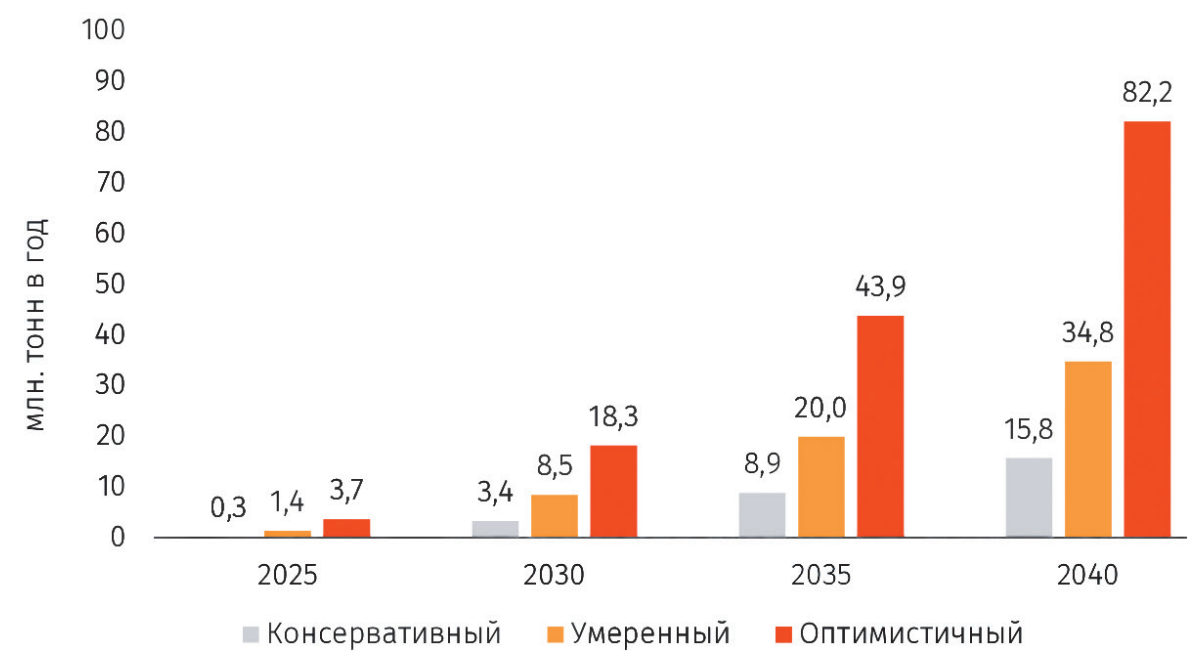

Рис. 4. Три варианта прогноза развития объемов мирового рынка водородного топлива [22]

составит 6,1 \% и к концу 2025 г. стоимость рынка достигнет 200 млрд. долл. этом показателе в 130 млрд. долл. в 2017 г. Рост рынка водорода в ближайшие годы будет тесно связан с переходом от углеродной к водородной мировой экономике, со снижением выбросов в атмосферу вредных парниковых газов и переходом на работающие на водороде транспортные средства.

Эксперты Hydrogen Council, прогнозируют, что благодаря переходу на водородную энергетику, к 2030 г. одна из двенадцати проданных в Калифорнии, Германии, Японии и Южной Корее машин могла бы ездить на водородном топливе. Согласно прогнозам аналитической компании Navigant Research, к 2024 г. количество транспортных средств с водородными топливными элементами в мире увеличится до 580 тыс., к 2026 г. до 800 тыс., а к 2030 г. - до 1,5 млн.

В докладе Hydrogen Council отмечается, что к 2050 г. эмиссия $\mathrm{CO}_{2}$ снизится на 60 \%, даже если население человечества к этому времени увеличится более чем на 2 миллиарда [2]. Будет создан рынок водорода в размере 2,5 трл. долл. и обеспечено рабочими местами более 30 млн. человек; до 400 млн. пассажирских транспортных средств ( $25 \%), 5$ млн. грузовиков ( $30 \%)$ и более 15 млн. автобусов будут работать на водороде; 20 \% поездов на дизельном топливе перейдут на водород; будут заменены в день около 20 млн. баррелей нефти, при этом спрос на водород может вырасти в 10 раз. Дается прогноз, что к 2050 г. на водород придется около $18 \%$ от всех энергетических потребностей в мире. Потребление водорода к этому времени увеличится до 370 млн. тонн в год, а к 2100 г. до 800 млн. тонн.

Организация ОРЕC (Petroleum Exporting Countries) оценила стоимость рынка водорода в 2018 г. в размере 118,1 млрд. долл. ОРЕС прогнозирует, что в период 2019-2025 гг. будет наблюдаться устойчивый спрос на водород на уровне 5,48 \% в год со стороны ряда промышленных отраслей [19].

Согласно оценке аналитической компании Research \& Markets, в период 2019-2024 гг. мировой рынок водорода будет развиваться со средней скоростью 5,8 \% в год [28]. Сейчас наблюдается увеличение спроса на водород со стороны химической промышленности, а также со стороны стационарных и портативных источников энергии. Технологии водородной энергетики становятся особенно популярными благодаря увеличивающейся коммерциализации технологий энергия-вгаз (power-to-gas) и растущему спросу на использование водорода в качестве транспортного топлива. А эксперты компании Mordor Intelligence делают прогнозы, что в период 2020-2025 гг. рынок водорода будет активно развиваться, и расти со скоростью более 5 \% в год, при этом рост рынка будет умеренно сдерживаться высокой ценой производства и транспортировки газа [31].

Что касается развития географии региональных рынков водорода, то согласно данным компании Persistence Market Research, самый высокий рост рынка в период 2017-2025 гг. будет наблюдаться в Азиатско-Тихоокеанском Регионе (АТР), Северной Америке и Европе [30]. Наиболее привлекательным является рынок стран АТР, в частности в Японии, где наблюдается устойчивый рост потребности в водородном транспортном топливе. Если в 2017 г. рынок АТР составил 35 млрд. долл., то к концу 2025 г. он должен увеличиться почти в два раза и превысить 70 млрд. долл. Более того, эксперты прогнозируют, что в ближайшие годы рынок водорода в АТР сможет достичь более одной 


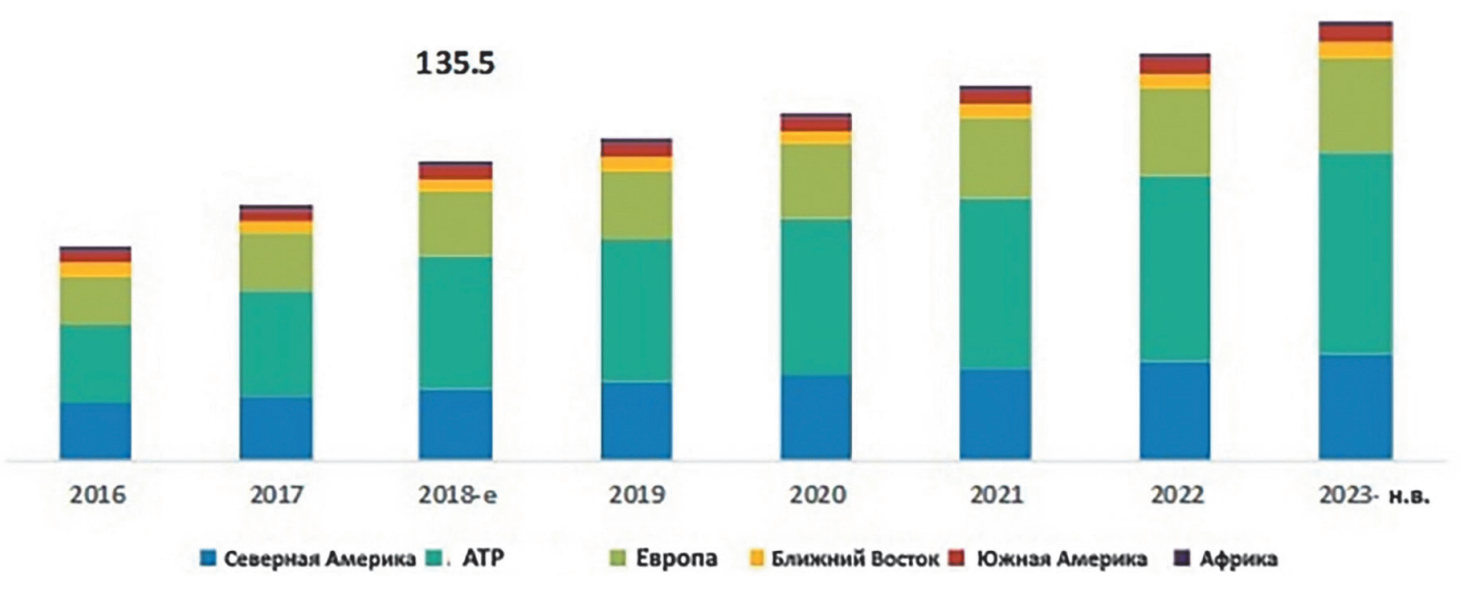

Рис. 5. Развитие региональных рынков водорода в период 2016-2023 гг. (млрд. долл. США)

135,5 млрд. долл. - стоимость мирового рынка водорода в 2018 г.; 199,1 млрд. долл. - прогноз стоимости к 2023 г. [29]

трети мирового рынка и будет развиваться с самой большой скоростью в мире. Вторым по величине региональным рынком водорода является рынок Европы, который в период 2017-2025 гг. будет увеличиваться со скоростью 6,4 \% в год.

Эксперты компании MarketsandMarkets отмечают, что в прогнозируемый ими период 2018-2023 гг. самым крупным по размерам региональным рынков также будет рынок АТР [29], который будет развиваться со среднегодовой скоростью $8 \%$ и с размеров 135,5 млрд. долл. в 2018 г. достигнет размеров в 199,1 млрд. долл. к 2023 г. (рис. 5).

А в прогнозе компании Research \& Markets на период 2019-2024 гг., самым быстрорастущим региональным рынком водородной энергетики окажется не рынок Азиатско-Тихоокеанского Региона, а рынок Северной Америки, где наблюдается устойчивый рост спроса на водородные топливные элементы, соблюдаются жесткие правила контроля эмиссии вредных парниковых газов и усиливается тенденция к использованию более чистых топлив [28]. Помимо Северной Америки, вторым крупнейшим региональным рынком станет Европа, где рост рынка будет связан в основном с увеличением числа транспортных средств, работающих на водородных топливных элементах, а также с развитием инфраструктуры, обеспечивающей безопасное хранение водорода.

При этом складывается впечатление, что мировые экономические и энергетические лидеры начинают рассматривать зарождающийся рынок водородных технологий как новый инструмент влияния и передела финансовых потоков. В частности, речь идет о сильнейшей конкуренции между США и Китаем за сферы влияния на водородном рынке.

\section{Потенциал развития водородной энергетики в России}

Аналитики рынка отмечают, что при выходе на мировой рынок водородного топлива Россия имеет определенные конкурентные преимущества, поскольку наша страна обладает обширной ресурсной базой и логистической близостью к традиционным рынкам сбыта водорода [32]. При этом России целесообразно развивать технологии и производство систем накопления энергии, которые будут востребованы как на внутреннем рынке, так и на экспортных площадках.

Исследования и разработки по системам накопления электроэнергии, включая водородную энергетику, поддерживаются и финансируются нашим государством. Общий объем госфинансирования этих работ по линии Минобрнауки и ФАНО в период 2014-2017 гг. составил более 1 млрд. рублей. Однако при этом отмечается, что российские разработки пока не выходят за рамки научных исследований и не превращаются в коммерческие продукты [32].

Распределение госфинансирования России по энергетическим системам (на технологии водородной энергетики пришлось $23 \%$ от общего финансирования всех энергосистем) в 2017 г. представлено на рис. 6 .

Под эгидой Национальной технологической инициативы в России в 2018 г. был запущен технологический конкурс «Первый элемент» по поиску новейших образцов топливных элементов, созданных на основе водородных технологий, в котором принимают участие ученые нескольких российских академических институтов, а Инфраструк- 


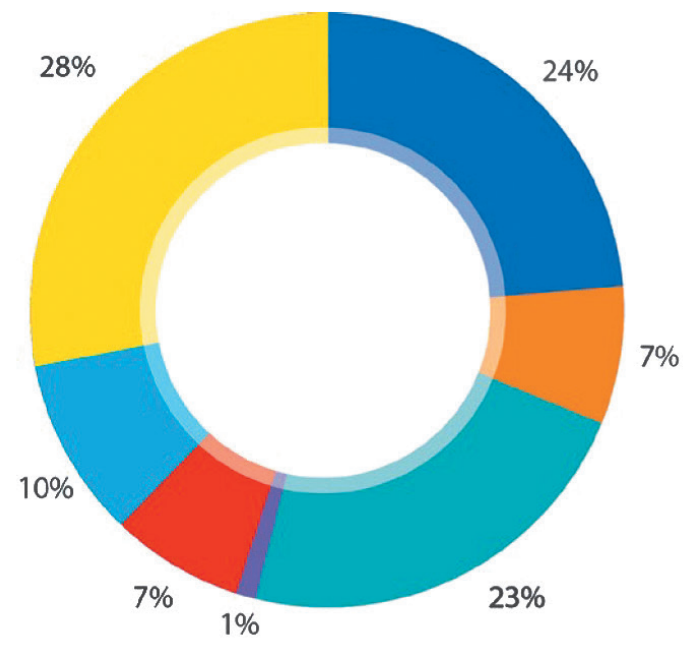

Электрохимические системы

и их компоненты

Электрические системы

и их компоненты

Технологии водородной энергетики

Механические системы и их компоненты

Диагностика

и испытания СНЭ

Моделирование компонентов СНЭ

Аналитика, прогнозирование, разработка концепций

\section{Рис. 6. Госфинансирование НИР и НИОКР по энергетическим системам со стороны Минобрнауки и ФАНО России в 2017 г.}

(СНЭ - система накопления энергии) [32]

турный центр EnergyNet совместно с Центром энергетики Московской школы управления СКОЛКОВО осуществляют работу с заинтересованными в водородной энергетике крупными российскими корпорациями [22]. Стартовала деятельность Центра компетенций по технологиям новых и мобильных источников энергии, основное направление НИР и НИОКР которого заключается в разработке новых материалов (в частности, для литий-ионных и постлитий-ионных аккумуляторов) и подходов к созданию топливных элементов и опытных образцов экспериментальных энергоустановок, работающих на водородных технологиях, ключевую роль в котором играет Институт проблем химической физики РАН $[33,34]$. Ряд лабораторий Института арктических технологий МФТИ совместно с Институтом проблем химической физики РАН, Институтом физики твердого тела РАН и Российским технологическим университетом МИРЭА проводят пионерские работы по созданию твердооксидных топливных элементов и катализаторов для систем хранения водорода в жидких органических носителях и аммиаке.

На совещании в Министерстве энергетики РФ 29 августа 2019 г., где присутствовали представители ряда российских научных центров и компаний (Газпром, Ростех, Росатом, Сибур), впервые на правительственном уровне было принято решение о разработке программы развития водородной энергетики России с использованием исследований специалистов EnergyNet [35]. Помимо прочих, в разрабатываемой программе должны найти отражение следующие положения:

- возможность использования технологий водородной энергетики на внутреннем рынке, по- требность в которых будет определяться спросом в регионах Крайнего Севера, Восточной Сибири и на Дальнем Востоке;

- наличие значительных топливно-энергетических ресурсов и учет огромного экспортного потенциала производства в России водородного топлива позволит нашей стране занять свою нишу на зарождающемся глобальном рынке энергетического водорода;

- декарбонизация транспортных средств с перспективой перехода на водородное топливо в сегментах большегрузного транспорта, бесшумного (в том числе железнодорожного) общественного транспорта, авиационных беспилотников;

- вопросы экологической безопасности, учет мировых трендов по замедлению глобального потепления и по декарбонизации экономики;

- наличие особых территориальных районов (Арктика) позволит России за счет водородных технологий создать свой безуглеродный стандарт энергетики и транспорта для освоения арктической зоны.

Несмотря на то, что сейчас вклад нашей страны в разработку и уж тем более в коммерциализацию водородных технологий еще очень мал, тем не менее, хорошо известно, что первый самолет с двигателем на водородном топливе был создан именно в СССР конце 1980-х годов (авиалайнер ТУ-155), а жидкое водородное топливо было в свое время задействовано в американских и советских космических программах (Space Shuttle и Буран) [36].

На протяжении последних трех лет в России наблюдается как спад, так и подъем производства водорода. В 2019 г. в России было произведено 1507886,0 тыс. м $^{3}$ водорода, что оказалось на $26,5 \%$ 
меньше объема его производства в 2018 г. Лидером производства водорода от общего произведенного объема за 2019 г. стал Приволжский федеральный округ (около 66,9\%). Производство водорода в апреле 2020 г. увеличилось на 39,8 \% к уровню апреля прошлого года и составило 114983,2 тыс. м $^{3}$ [37].

Развитие современного рынка водородной энергетики в России должно определяться явными конкурентными преимуществами страны: наличием сырьевой базы и резервов производственных мощностей, близостью к потенциальным потребителям продукции (страны ЕС, КНР, Япония), имеющейся действующей инфраструктурой транспортировки природного газа [38].

Известно, что водород уже сейчас успешно производится в России, однако не в качестве топлива, а в основном находя применение в нефтепереработке, металлургии и химической промышленности. В то же время России существуют большие возможности производства топливного водорода на ряде российских гидроэлектростанций и атомных электростанций. Однако, согласно докладам EnergyNet [22], на сегодняшний день многие производственные мощности России, способные накапливать электроэнергию в водородном топливе (Усть-Среднеканская ГЭС в Магадане, Ленинградская АЭС, Кольская АЭС) загружены не на полную мощность (так называемые «запертые мощности»). Кроме того, необходимы меры господдержки и разработки отечественных регламентов по промышленной безопасности использования водородных автомобилей.

У России имеется хороший задел в области разработок водородных топливных элементов. В частности, летом 2018 г. в Москве был представлен первый российский автомобиль с водородными топливными элементами (475 Вт ч/кг, вес 42 кг), а следом за ним в Санкт-Петербурге был выпущен на линию первый тестовый трамвай, работающий на водородном топливе. Согласно [11], хотя водородные баллоны и топливные элементы этих транспортных средств пока еще далеки от совершенства и имеют очень большие габариты, а скорости передвижения транспорта на их основе пока остаются очень низкими, тем не менее, модернизация и доработка российских водородных технологий в целом является вопросом времени и выделяемых инвестиций.

Несмотря на то, что массовый переход мировых авиакомпаний на водородное топливо ожидается не раньше середины XXI века, исследования водородных технологий для авиационной отрасли, где наша страна уже имеет большой практический опыт, продолжаются. На авиасалоне МАКС-2019 Центральный институт авиационного моторостро- ения им. Баранова представил модель малого самолета «Сигма-4» на водородной тяге. Электродвигатель будет питаться от двух источников: литиевых аккумуляторных батарей и твердополимерного водородного топливного элемента. Водородная силовая установка, энергоэффективность которой в 2,8 раза выше, чем при сжигании керосина, сильно уменьшена в размерах и занимает в самолете одно пассажирское место [39].

В целом развитие водородной энергетики в России будет ориентировано на экспортную составляющую. Так, сценарий развития накопления электроэнергии в водородном цикле, представленный в экспертно-аналитическом докладе Центра EnergyNet [22], прогнозирует масштабное развитие экспортного водородного потенциала России с возможным получением экспортной выручки в объеме 1,7-3,1 млрд. долл. уже к 2025 году, что позволит претендовать на 10-15 \% мирового рынка водорода к 2030 г. Наиболее вероятным импортером российского водорода может стать Япония, закупающая водород из Австралии и Катара по цене 4,6 долл./кг и из США и Норвегии по цене 5,2-5,4 долл./кг (Россия же сможет предложить водород по более низкой цене в 3,38 долл./кг). Авторы доклада полагают осуществить пилотный проект по получению водорода на базе гидроэнергетических или ветроэнергетических мощностей на Дальнем Востоке (Усть-Среднеканская ГЭС им. Дьякова, ветрогенераторы на о. Сахалин).

На рис. 7 представлен прогноз роста рынка систем накопления электроэнергии для экспортных поставок водородного топлива из России на основе создания крупнотоннажного электролизного производства водорода и систем его дальнейшей транспортировки [22].

Согласно прогнозам EnergyNet [32], в ближайшие годы рынок водородной энергетики в России будет активно развиваться и в 2025-2035 гг. может достичь объемов в 2,2-3,9 млрд. долл. (объем мирового рынка в 2025 г. составит 26 млн. долл.). К 2030 г. Россия сможет производить уже 3,5 млн. тонн водородного топлива. Развитие внутреннего рынка водородного топлива в России будет стимулироваться не только спросом со стороны традиционных областей потребления, но также и возможностью аккумулирования энергии в водородном цикле для повышения энергоснабжения удаленных и изолированных территорий (в основном, на Крайнем Севере и Дальневосточном регионе), где можно будет сформировать локальные системы эффективного производства и транспортировки водорода.

Конкурентные преимущества России на мировом рынке водорода: существующие резервы про- 


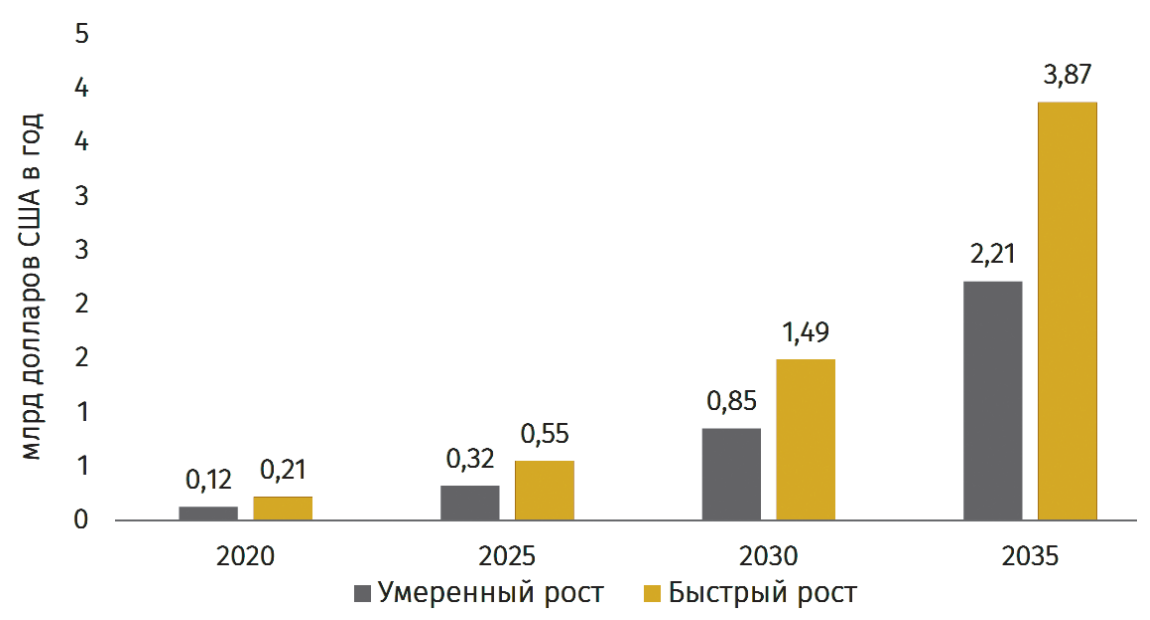

Рис. 7. Прогноз роста российского рынка систем накопления электроэнергии в водородном цикле для экспортных поставок водородного топлива [22]

изводственных мощностей, близость к потенциальным потребителям (страны ЕС, КНР, Япония), наличие действующей инфраструктуры транспортировки природного и сжиженного природного газа [35].

\section{Заключение}

В связи с наметившейся перспективой перехода к низкоуглеродной энергетике в XXI веке прогнозируется резкое увеличение спроса на водород, так как многие отрасли перейдут на новые способы производства высококачественной продукции с использованием водорода, будут востребованы экологически чистый транспорт и системы распределенного энергоснабжения, работающие на водородных топливных элементах. Ключевая задача молодой водородной энергетики: в целях наметившейся декарбонизации мировой энергетической системы развернуть эффективное производство водорода в промышленных масштабах. В случае организации крупного конкурентоспособного отечественного производства водорода для нашей страны откроются возможности выхода на мировой рынок водорода и сопутствующих продуктов с высокой добавочной стоимостью.

Несмотря на то, что становление и развитие мирового рынка водорода связано с серьезными трудностями (стоимость производства, хранение и транспортировка, специфика инфраструктуры водорода), последние научные и прикладные исследования и разработки показали, что в решении этих вопросов наблюдается явный прогресс, который может обеспечить широкое использование водорода в качестве экологически чистого источника энергии и сырья для получения широко востребованных химических и нефтехимических продуктов.
Работа выполнена в рамках Программы фундаментальных научных исследований государственных академий наук, тема ИПХФ РАН 0089-2019-0018 (Номер госрегистращии АААA-A19-119022690098-3)

\section{Литература}

1. Staffell I., Scamman D., Abad A.V., Balcombe P., Dodds P.E., Ekins P., Shan N., Ward K.R. Energy Environ. Sci. 2019. V. 12. P. 463. DOI: $10.1039 / \mathrm{c} 8 \mathrm{ee} 01157 \mathrm{e}$

2. Hydrogen scaling up. A sustainable pathway for the global energy transition. Hydrogen Council. November 2017. URL: https://hydrogencouncil.com/wpcontent/uploads/2017/11/Hydrogen-scaling-up-Hydrogen-Council.pdf.

3. Митрова Т., Мельников Ю., Чугунов Д. Водородная экономика - путь к низкоуглеродному развитию. Центр энергетики Московской школы управления СКОЛКОВО. Июнь 2019. URL: https://energy. skolkovo.ru/downloads/documents/SEneC/Research/ SKOLKOVO_EneC_Hydroren-economy_Rus.pdf

4. EU EDGAR Database (Joint Research Centre (European Commission), 2018. Fossil CO2 emissions of all world countries, 2018 report. URL: https://edgar.jrc. ec.europa.eu/overview.php? $\mathrm{v}=$ booklet 2018

5. Макарян И.А., Седов И.В., Никитин А.В., Арутюнов B.C. Научный журнал российского газового общества. 2019. т. 24. № 1. с. 38.

6. Макарян И.А., Седов И.В. Максимов А.Л. Журнал прикладной химии. 2020. т. 93. вып. 12. С. 1716.

7. Hydrogen Council. URL: https://hydrogencouncil.com/ $\mathrm{en} /$

8. Jocelyn Timperley. Renewable hydrogen "already cost competitive", says new research. March 15, 2019. URL: https://energypost.eu/renewable-hydrogen-already-cost-competitive-says-new-research/

9. Водородная энергетика: инновационный проект XXI века. URL: https://www.eprussia.ru/epr/71/4879.htm

10. Мельников Ю., Чугунов Д. Водородная экономика: разрушит ли новое топливо «ископаемую» циви- 
лизацию. URL: https://www.forbes.ru/biznes/358673vodorodnaya-ekonomika-razrushit-li-novoe-toplivo-iskopaemuyu-civilizaciyu

11. Гриб Н. Водородная энергетика: мифы и реальность. URL: http://www.ngv.ru/magazines/article/ vodorodnaya-energetika-mify-i-realnost/

12. IEAGHG, Techno-Economic Evaluation of SMR Based Standalone (Merchant) Plant with CCS. February, 2017. URL: https://ieaghg.org/exco_docs/2017-02.pdf

13. Jun Chi, Yu. Hongmei. Chin. J. Catal., 2018. v. 39. p. 390.

14. Lee B., Heo J., Kim S., Sung Ch., Moon Ch., Moon S., Lima H. Energy Convers. Manage. 2018. V. 162. P. 139.

15. Caoa L., Yua I.K.M., Xionga X., Tsanga D.C.W., Zhangb S., Clarkc J.H., Hue Ch., Ngf Y.H., Shangf J., Ok Y.S. Environmental Research. 2020. v. 186. p. 109547. DOI: 10.1016/j.envres.2020.109547.

16. A novel biofuel system for hydrogen production from biomass. Ulsan National Institute of Science and Technology. March 2, 2020. URL: https://phys.org/ news/2020-03-biofuel-hydrogen-production-biomass. html

17. Водородная энергетика - тренд XXI века. URL: http://atomicexpert.com/hydrogen energy

18. На российских АЭС создадут масштабное производство водорода. 7 мая 2020. URL: https://teknob$\log . r u / 2020 / 05 / 07 / 105350$.

19. Hydrogen Market - Industry Analysis, Market Size, Share, Trends, Application Analysis, Growth and Forecast 2019-2025. URL: https://www.industryarc.com/ Research/Hydrogen-Market-Research-501664

20. Hydrogen Market Overview. Industry Analysis Report, 2024. Prescient \& Strategic Intelligence. URL: https:// www.psmarketresearch.com/market-analysis/hydrogen-market

21. The cost of hydrogen: Platts launches Hydrogen Price Assessment. By Trevor Brown on December 19, 2019. Ammonia Energy Association. URL: https://www.ammoniaenergy.org/articles/the-cost-of-hydrogen-plattslaunches-hydrogen-price-assessment/

22. Перспективы России на глобальном рынке водородного топлива. Инфраструктурный центр EnergyNet. Экспертно-аналитический доклад. Москва, 2019. URL: https://www.eprussia.ru/upload/iblock/ede/ ede334adeb4c282549a71d6fec727d64.pdf

23. S\&P Global Platts launches world's first hydrogen price assessments. London (December 18, 2019). URL: https:/www.spglobal.com/platts/en/about-platts/media-center/press-releases/2019/18-12-2019-hydrogenlaunch

24. Tayade P., Sapkal V., Rode C., Sapkal R. International Journal of Advances in Engineering \& Technology. 2012. V. 3 (1). Р. 436.

25. Водородная энергетика. Хранение солнечной энергии в «твёрдом водороде». Март 2020. URL: https:// energy.hse.ru/hydrenergy
26. Randolph K. U.S. DOE. Hydrogen production - Session introduction, 2013 Annual Merit Review and Peer Evaluation Meeting, May 16, 2013. URL: https://www.hydrogen.energy.gov/review13/pd000_randolph_2013_o.

27. U.S. Department of Energy (DOE). URL: https://www. hydrogen.energy.gov/index.html

28. Hydrogen Energy Storage Markets 2019 - Global Forecast to 2024. Oct 22, 2019. URL: https://www.prnewswire.com/news-releases/hydrogen-energy-storage-markets-2019-global-forecast-to-2024-300942023.htm

29. Hydrogen Generation Market. URL: https://www.marketsandmarkets.com/Market-Reports/hydrogen-generation-market-494.html

30. Global Market Study on Hydrogen: Robust Growth in the Adoption of Hydrogen Across Various Applications to be Observed in North America in the Coming Years. Persistence Market Research. URL: https:// www.persistencemarketresearch.com/market-research/ hydrogen-market.asp

31. Hydrogen Gas Market - Growth, Trends, and Forecast (2020-2025). URL: https://www.mordorintelligence. com/industry-reports/hydrogen-gas-market

32. Рынок систем накопления электроэнергии в России: потенциал развития (под редакцией Ю. Удальцова и Д. Холкина). Роснано, Энерджинет. Москва, 2018, 72 c. URL: https://www.csr.ru/wp-content/uploads/2018/07/Condenses_system_markets_in-Russia_ Internet_M5.pdf

33. Arkhangel'sky, I.V., Kravchenko, O.V., Tsvetkov, M.V. et al. Russ J Appl Chem. 2019. V. 92. P. 734. DOI: 10.1134/S1070427219060028.

34. Solovev M.V., Oleg V. Chashchikhin O.V., Dorovatovskii P.V., Victor N. Khrustalev V.N., Zyubin A.S., Zyubina T.S., Kravchenko O.V., Zaytsev A.A., Dobrovolsky Yu.A. Journal of Power Sources. 2018. V. 377. P. 93.

35. России предстоит занять нишу на зарождающемся глобальном рынке энергетического водорода. URL: https://ntinews.ru/news/khronika-rynkov-nti/energynet/ rossii-predstoit-zanyat-nishu-na-zarozhdayushchemsyaglobalnom-rynke-energeticheskogo-vodoroda.html

36. Митрова Т., Мельников Ю., Чугунов Д., Глаголева А. Водородная энергетика покоряет континенты. Газета «Энергетика и промышленность России» № 19 (375). Октябрь 2019 года. URL: https://www.eprussia. ru/epr/375/565500.htm

37. Рынок водорода в России. Текущая ситуация и прогноз 2020-2024 гг. URL: https://alto-group.ru/otchot/ rossija/834-rynok-vodoroda-tekushhaya-situaciya-iprognoz-2017-2021-gg.html

38. В России появится программа развития водородной энергетики. URL: https:/www.vedomosti.ru/business/articles/2019/09/01/810161-minenergo-razrabotaet-programmu

39. Россия станет одним из лидеров мировой водородной энергетики. URL: https://teknoblog. ru/2019/12/06/102829 